\title{
Ideology in the Era of Xi Jinping
}

\author{
Kerry Brown ${ }^{1} \cdot$ Una Aleksandra Bērziṇa-Čerenkova ${ }^{2}$
}

Published online: 23 February 2018

C The Author(s) 2018. This article is an open access publication

\begin{abstract}
After 1978, Maoism as a living mass ideological and social force in the People's Republic of China largely died away. The Party state's legitimacy since that time has been based on a new pillar of economic competence and the delivery of tangible economic gains. But China is still a place where, at least within the political elite, there is an identifiable ideology and associated language that links the aims of a political force, the Communist Party of China, with national prosperity, historic rejuvenation, and the delivery of the political goals promised when the Communist Party was founded almost a century ago - modernity in Chinese society. Ideology has not disappeared in this interpretation. It has just become more concealed, more nuanced, and in some spaces more flexible. For Chinese contemporary leaders, ideology is partly a body of practices, beliefs, and language which have been bequeathed to them by previous leaders, and which show that they are part of the same historic movement that runs from 1921 to 1949, and through 1978 until today. This body of practices is aimed at maintaining a sustainable system of one party rule, as well as an assertion of discipline and control in the core tactical spaces of political power. Under $\mathrm{Xi}$, a group of twelve keywords maps out the discursive space that matters to the CPC today. These terms exemplify the ways in which the contemporary CPC is willing to use ideas from diverse sources, either from its own past, or from classical Chinese thinking, as a means of achieving emotional as well as intellectual impact, and to assist in the delivery of the major Party goal of the twenty-first century - the creation of a great nation with the CPC at the heart of its governance. Underlying the keywords and the ideological space they define is the larger notion of the Party, not just attending to material but also spiritual needs - and creating not just a wealthy country, but also a spiritual socialist civilization.
\end{abstract}

Keywords Ideology $\cdot$ China $\cdot$ Xi Jinping $\cdot$ Centennial goals $\cdot$ Spiritual civilization · Ideological hybridity

Kerry Brown

1 Canterbury, UK

2 Rīga LV-1003, Latvia 


\section{Introduction}

If we take the expansive definition of ideology offered by a cultural theorist such as Terry Eagleton, where ideology is 'the process of production of meanings, signs, and values in social life; a body of ideas characteristic of a particular social group or class; ideas which help to legitimize a dominant political power', then to some extent what is broadly understood as ideology matters in every society ( [1], 2-3). From the United States, with its constitutionalism, libertarianism and modern faith in the wisdom of free markets, to the Democratic People's Republic of Korea, with its narrow interpretation of Marxism and a large dose of local nationalism, we find that ideology is everywhere. The question is more about how it manifests itself from place to place, how it is embedded in political and social life, and in what ways it figures as a resource for different kinds of political, business and other leaders and their networks and followers. In this context, the People's Republic of China, with its commitment to a MarxistLeninist party having the monopoly on power, provides a particularly rich object of study, both through the keywords it adopts and in the ideological associations and context used by its elite leaders, as well as in the very specific power structures whereby this is conveyed.

From 1949 to 1976, the People's Republic of China was seen as a highly ideological society. Studies from Schurmann and Hsiung from this era testify to that. There was a specific Party State dogma, some of which was borrowed from the international movement of Communism, and some of which was home-grown. Scholars such as John Lewis and A. Doak Barnett analysed the ideology of this time with its recognized vocabularies and discourses within an institutional context. The result was a clearly designated formation that came to be called Maoism, which could be broadly described as a belief in the achievement of Utopian social goals by means of class struggle and the cleansing of society in order to create an egalitarian society. The Cultural Revolution, which ran from 1966 to 1976 and underwent various phases of intensity, marked the high point of the development and impact of this on Chinese society. (See [2], and [3], 106-147).

Since 1978, this iteration of Maoism as a living ideological and social force has largely died away, despite the adherence of some small groups and individuals. It seems to exist in the language of the current leaders of the Communist Party of China (CPC) as something akin to a rhetorical stain; present in words, but with no underlying prescriptive force that reaches into wider society. The class struggle is, at least as an ideological concept of the Mao era, over. It was replaced after the Third Plenum of the Eleventh Party Congress in December 1978 by something more akin to an indigenous pragmatic ideology, best summarized by the formulation 'market socialism with Chinese characteristics.' ( [4], 1-32).

Many things that were anathema prior to 1978 , such as the acceptance of a non-state sector, foreign capital, and domestic markets, became permissible afterwards. So, while in the Maoist period the Party state's legitimacy was based to some extent on strengthening the country by economic means, the ways in which it did this fundamentally changed, shifting from a complete command economy model before 1978 to a more hybrid, pragmatic one after this date. The delivery of tangible material outcomes for families and individuals became permissible, rather than the collective approach with communes and work brigades that had prevailed in the period of high socialism up to 
1978. Such a shift in approach has served the People's Republic of China and its ruling CPC well in terms of achieving its targets, with China crowned as the world's second largest economy in 2010, having lowered the headcount of people living below the poverty line to an unprecedented $6.47 \%$ by $2012 .{ }^{1}$ Dengist pragmatism has kept the $\mathrm{CPC}$ in power. But even though it took a looser institutional and rhetorical form than Maoism, this article would argue that the idea of China post-1978 as marking a nonideological era for the country is erroneous. Since 1978, ideology has become more concealed, more nuanced, and in some spaces more flexible, but it has lost none of its importance to the Party and its mission to stay in power. Contemporary China is still a place where there is an identifiable ideology and its keywords and language continue to link the aims of a political force, the CPC, with national prosperity, historic rejuvenation, and the delivery of the political goals promised when the Communist Party was founded almost a century before, i.e., modernity in Chinese society.

\section{What do Chinese Leaders Believe - and Does it Matter?}

People outside China often ask what Chinese leaders believe. On the surface, this is a hard question to answer definitively. Based on the language they use, they seem to believe something - Marxism Leninism and state socialism - which is often at odds with the society around them, which has embraced markets, entrepreneurialism, and often appears to be more capitalistic than ostensibly capitalist societies such as the US, UK or Australia. Is it the case that Chinese leaders are hypocrites and confused, or is it that they just believe something no one else around them does, something that, happily, does not interfere with the material development of their society? Why is it that they seem to say one thing, while in the wider society everyone else practices something different? Perry Link has gone as far as to argue that Chinese leaders neither believe not disbelieve a particular ideological assertion, but rather consider whether a particular issue will serve or not serve their political goals. ( [5], 283-284) Developing this line of thought, the current essay will argue that they do in fact stand by the ideology contained in their words - but that this is not an issue of belief in a set of propositions contained in that ideology per se, but more because this ideology and its keywords and language create a consensus, marrying the current leaders to those of the past, and thus having utility. ${ }^{2}$

Deng was the great articulator of this idea. As his biographers have made clear, it is questionable whether he read any more Marx and Engels than Ronald Reagan or George W Bush read Adam Smith. ${ }^{3}$ But he did stand by the idea that Marxism, when applied to China, had a practical value, and that this was something that history had

\footnotetext{
${ }^{1}$ According to the World Bank PovcalNet database, search results available at http://iresearch.worldbank. org/PovcalNet/povOnDemand.aspx [accessed June 20, 2017]

2 The idea of Chinese leaders using their words as a kind of performance utterance, where the simple act of saying something is more important than its content, is best exemplified by the study by [6]. Doing Things with Words in Chinese Politics. Berkeley: University of Berkeley Press.

${ }^{3}$ See, for instance, [7]. Deng Xiaoping: A Revolutionary Life. Oxford: Oxford University Press. See also Deng's own statement in 1991-2, when on his famed 'Southern Tour': 'It was from the Communist Manifesto and the $\mathrm{ABC}$ of Communism that I learned the rudiments of Marxism... Marxism is the irrefutable truth. The essence of Marxism is seeking truth from facts. That's what we should advocate, not book worship... Actually, Marxism is not abstruse. It is a plain thing, a very plain truth.' [8]. Excerpts From Talks Given in Wucheng, Shenzhen, Zhuhai, and Shanghai. Beijing: Foreign Languages Press.
} 
proved. Ideology, therefore, was a set of statements about the reality of the world as seen from China's vantage point, which at least served to forge Party unity, to answer hard questions facing the Party, to strengthen the master narrative of the 'party spirit' (dangxing) and deliver consensus. ( [9], 244) It addressed the explosion of debilitating confusion that China had experienced in the Republican era, when there was a marketplace of ideas, but also a chaotic clash between different power structures resulting in domestic and external fragmentation. Therefore, while foreign scholars such as Frank Dikötter speak of the Republican period from 1911 to 1949 as being, at times, a halcyon era of pluralism and openness, for China's leaders after 1949 it was a period blighted by disunity, weakness, poverty and tragic vulnerability in relation to foreigners. (See [10]).

For Chinese contemporary leaders, therefore, a unified ideology is partly viewed as a key means of avoiding the fracturing that the country has experienced in modern times. It also figures as a body of practices, beliefs, and language that has been bequeathed to them by previous leaders, and shows that they are part of the same historic movement that runs from 1921 to 1949 , and through 1978 until today. This ideological consistency shows that they are delivering goals that are part of a historic inevitability, resulting from the operation of Marxist dialectics. But ideology also has organizational utility. Most of the 88 million members of the CPC in the second decade of the twenty-first century do not ask searching, profound questions about just how 'true' and realistic the stated belief system of the political organization they belong to is. In some ways, the CPC is a faith community, where tenets of Marxism-Leninism are accepted instinctively and unreflectively because they still remain an established part of the worldview and practices of the CPC. Ideology in this organizational context forms part of the broader culture of the CPC and is important because it signifies and carries that common culture. This paper looks at the particular ways that this utilitarian side of ideology has been manifested in the tight subset of discourse contained in the major speeches of elite leaders in the decade since 2007, and how they illustrate this functioning of ideology as an organizational, cultural trait. Particular focus will be directed at the keywords that have been used in the era of Xi Jinping and what these betray about control, discipline and the attempt by the CPC to relegitimise itself through the use of older, traditional strands of Chinese belief systems, revitalized and presented in a new political context. These testify to the hybridity of contemporary Chinese CPC ideology.

\section{Hu Jintao - Ideology during the Era of Technocratic Leadership}

To understand the $\mathrm{Xi}$ era, we need to look briefly at the one that preceded it. In the era of $\mathrm{Hu}$ Jintao, from 2002 to 2012, the main members of the Politburo Standing Committee came from academic and leadership backgrounds that can be described as technocratic. Of the nine-strong elite leadership from 2002 to 2007 under the 16th Party Congress, all had studied various aspects of engineering or hard sciences. From 2007 to 2012 the composition was slightly more diverse and included a lawyer (Li Keqiang). The background of leaders was not just technocratic in terms of their tertiary education experience. They were the result of a long training process that had seen them progress through provincial and central ministries, where politics was almost regarded as a 
technical vocation to be learned through painstaking practice and administrative experience. In this era, Chinese leaders formulated ideas that were presented at large Party meetings as contributions to and developments of standard ideology. As political parties in the west undertook campaigns to gain support for promoting and achieving policy goals, so too the CPC leadership tried to adapt its position so that it did not jettison its links with the CPC's past but stated things that could be broadly relevant to China's evolving economic and social position. Under Hu Jintao, the General Secretary of the CPC, the most important formulation, enshrined in the Party Constitution of 2007 at the 17th Party Congress that year, was 'Scientific Development' (kexue fazhan).

In Chinese publications, 'Scientific Outlook on Development' is described as a theory, based on the Marxist development worldview and methodology, which forms a continuous line with Marxism-Leninism, the thoughts of Mao Zedong, the theory of Deng Xiaoping and the 'Three Represents', an idea devised by Jiang Zemin when Party Secretary before 2002, aimed at enfranchising the non state sector by allowing it to join the Party. 'Scientific Development' was presented as the next step in the Sinicisation of Marxist thought carried out by the CPC.

'Scientific Development' at that time was presented as part of the journey of developing state- and party-building theory. It was regarded by elite leaders as being a natural progression from, not a rupture with, previous dominant ideological formulations. However, despite the somewhat abstract sound, it was also more pointedly a response to a very specific set of questions about inequalities, imbalances and structural problems in contemporary Chinese society that stemmed from the unequal impact of rapid economic development following the country's entry into the World Trade Organization in 2001. ${ }^{4}$ The simple fact is that over this period, while China on the surface had grown increasingly capitalistic, allowing marketization to spread to further areas of the economy, the CPC had been asserting the need for a unified political centre, and for a continuation of its monopoly on political power.

'Scientific Development' contained a number of key themes. It made it clear that economic and social development remained the top priority of the Party. In order to help close the gap between officials and the people they were meant to be serving, the idea also utilized the ancient Chinese phrase from the philosopher Mencius of 'putting people first'/"person as the core' (yi ren wei ben). This was to address the rising criticisms of Party officials as being remote, corrupt and living in a separate realm from normal people. Part of this was an attempt to achieve sustainable, more equitable growth.

In his 17th National Congress of the CPC report in 2007, Hu went out of his way to praise the success of China's post-1978 development. But he did admit that the country needed to deal with a relatively new set of problems, ranging from the uneven distribution of growth across regions, industries and social classes, to economic challenges such as low productivity and the lack of substantial innovation, as well as such social issues as the income gap and urban-rural misbalances. On top of these issues, there were institutional and structural ones, such as the lack of impartiality within the legal system.

Social justice within the 'Three Represents', ushered in under Jiang, was addressed by calling for the wellbeing of people as a whole (renmin). One difference from

\footnotetext{
$\overline{{ }^{4} \text { Here, and further quoted, from: }}$ [11].
} 
'Scientific Development' was the way in which it talked about the person, the single human and his/her interests, centring on the word 'person' (ren). Hu breathed life into the formula 'person as the core' and declared this to be the prime objective of the new ideological formulation. This upended the bias of previous ideological formulations, which had privileged collective stances over those based on the individual.

Whatever the tactical merits of this Hu-era formulation, however, there was still a problem: a widespread lack of public interest in the idea outside elite Party circles. Despite its intense usage during the final years of the $\mathrm{Hu}$ era in official publications such as the 'People's Daily' and elsewhere, as evidenced by the keyword analysis chart generated by the Chinese Academic search Website sciinfo.cn, the use of the phrase yi ren wei ben entered a steep decline in 2013-14. This occurred precisely after the leadership change around 2012 that marked the transition from $\mathrm{Hu}$ to $\mathrm{Xi}^{5}{ }^{5} \mathrm{~A}$ similar fate has befallen the use of 'Scientific Development'. Although Xi Jinping's take on 'Scientific Development' still appears in analytical publications as of May 2016, he began distancing himself from Hu's definitions as soon as he replaced $\mathrm{Hu}$ as head of the CPC.

\section{Xi Jinping: the Rhetorical and Political Use of Ideology}

Xi might have ceased using the terminology and discourse of 'Scientific Development' but the underlying set of problems this idea was meant to address and overcome, listed in the section above, did not go away. Nor did the fundamental problem of the Party elite and their language being remote from the lives of most people in China. The era of $\mathrm{Xi}$, therefore, can be seen not as a dramatic break with the one that preceded it, but more as one where the same issues are being tackled with a different set of political and ideological tools. Once more, the onus is on continuity, evolution and development in the realms of action and thought, not revolution and the dramatic abandonment of the past.

In many ways, one of the starkest differences between the eras of $\mathrm{Hu}$ and $\mathrm{Xi}$ is a return to the primacy of politics, rather than a relentless focus on economic performance and the achievement of tangible economic outcomes. The Party almost seemed to disappear from public view during Hu's breakneck pursuit of development and enrichment for China. During the Hu years, with a 5.8 times growth in GDP, ${ }^{6}$ party discipline almost collapsed. An ostensibly Marxist-Leninist political entity found itself at the heart of one of the greatest creations of national wealth the world had ever seen. China's economy quadrupled in size between November 2001 and 2012. The side effect of this was that Party officials confused their entrepreneurial and political functions, with many (perhaps the vast majority) succumbing to corruption and larceny. Enormous amounts of state wealth disappeared into the pockets of private networks and vested interests. Sectors such as the state oil, telecom, and construction industries came to be dominated by particularly defined, in many cases family, elite networks. (See

\footnotetext{
${ }^{5}$ Search results available at: http://www.sciinfo.cn/result.aspx? $\mathrm{c}=001001 \& \mathrm{q}=$ 以人为本 $\& \mathrm{p}=1$ [accessed May 15, 2016]

${ }^{6}$ The World Bank. China - GDP growth. Search results available at: http://data.worldbank.org/indicator/NY. GDP.MKTP.KD.ZG?end=2013\&locations=CN\&start=2003 [accessed July 20, 2017]
} 
[12]) The CPC was in the anomalous position of having risen to power in order to bring down inequality and injustices in Chinese society, and yet presiding over high levels of inequality and dissatisfaction. It is not surprising, therefore, that the first words uttered by Xi on appointment as Party leader in November 2012 were about the urgent need to address this widening gap between the ruling elite and the people. Party building and its attendant enforcement of discipline through the anti-corruption struggle became the immediate means of achieving this.

In an era where greater focus is placed on politics and the role of the Party, ideology naturally figures under $\mathrm{Xi}$ as a core dimension of power. The immediate task undertaken by Xi Jinping in order to preserve and reaffirm ideology was to reassure the public that there existed a level of continuity and solidarity among leadership generations, paying respect to the legacy of power of the CPC in a speech at the Central Party school on January 5, 2013. In the spirit of such continuity, Xi went as far as to build a symbolic bridge with the Qin dynasty by quoting a poem by the calligrapher and writer Zheng Xie when calling for confidence in the path, theory, and system. ${ }^{7}$ The most important message of the speech, however, was the concept of "the two that cannot be denied" (liangge bu. neng fouding) - the post-Reform and Opening up period cannot be used to deny the pre-Reform and Opening up period, and vice versa. It was made clear that correcting mistakes and learning lessons was an acceptable part of the process, but that there could be no refutal of the path chosen by China in 1949. ( [13], 22-23).

Ideology is strategic because it plays a crucial role in delivering sustainable one party rule and in ensuring that in an era of flat-lining GDP growth and increasing social, economic and political challenges the Party is able to survive, to occupy its crucially important coordinating role in society, and to ensure that no organized opposition forms against it. The assertion of discipline can be seen in the issuance of lists such as Document Number Nine by the Central Committee in $2013,{ }^{8}$ which prescribed university teachers from being seen to promote multi-party democracy, constitutionalism, and bicameral parliaments in their lessons. The enforcement of organizational discipline can be seen as part of the clearing away of official malfeasance, the removal of corrupt officials, and the stress on party unity and cohesion. At the heart of this is a focus on the control of the core tactical spaces where the Party needs to assert dominance in order to ensure that it achieves middle-income status for China by 2021 and avoids the demise of the Party as in the Soviet Union, cited an example of what can go wrong when Party strategy goes awry and leaders lose sight of their core political mission.

This attempt to extend control over the political and ideological space within China is best exemplified by the 'Four Comprehensives' (or 'Four Pronged Strategy', Sige quanmian zhanlue buju 四个全面战略布局) issued in February 2015. The idea first surfaced during an inspection tour that $\mathrm{Xi}$ undertook of the southern province of Jiangsu in December 2014, but was formally announced by the Renmin Ribao (People's Daily) in February of the following year. The four objectives covered were:

\footnotetext{
7 An earlier version of the "Four confidences".

${ }^{8}$ Although the full text has been removed from circulation, a scanned article from "Liaoning Ribao" and an explanation of the contents of the Document can be found at: 'Zhonggong xiafa yishixingtai wenjian tongbao shenlong bu. jian shou wei' May 13, 2013, http://www.bbc.com/zhongwen/simp/china/2013/05/130513_ china_politics_ideology.shtml
} 
- Comprehensively build a moderately prosperous society

- Comprehensively deepen reform

- Comprehensively govern the nation according to law

- Comprehensively strictly govern the Party.

Labelled somewhat grandiloquently as an 'unprecedented and strategic leap forward' in the state-owned Global Times, a publication that has become infamous for its nationalistic and sometimes bombastic and strenuous support for populist positions, the first three established pedigree within state information campaigns. ${ }^{9}$ Seeking to build a moderately prosperous society had been part of the $\mathrm{Hu}$ era mission, linked to the phrase 'moderate prosperity' (xiaokang). 'Comprehensively deepening reform' had figured as a slogan since the Third Plenum in 2013, when Xi and his colleagues had issued extensive policy proposals and an explanatory framework. ${ }^{10}$ Linked to notions of the use of the market to forge greater productivity, efficiency and innovation in the stateowned sector, and to the creation of greater dynamism and sustainability in the rest of the economy, a new Leading Small Group was set up later that year, chaired by Xi, with the mission to 'comprehensively deepen reform.' The ambition to govern according to the rule of law was invoked in the following Plenum, a year later in October 2014, where the commitment to having a socialist legal system was set out.

It was the final leg of this 'four comprehensives' (strictly governing the Party) that attracted the most attention. Commentary in outlets such as the BBC argued that this was a specific reference to the current anti-corruption campaign being promoted by $\mathrm{Xi}^{11}$ This made it clear that the Party itself was a target of reform, a part of the whole terrain being focused on, not something outside it, operating in a privileged zone of its own. ${ }^{12}$ In the $2000 \mathrm{~s}$, there had been a discussion among elite leaders regarding the Party's right to rule. Figures such as Bo Xilai, subsequently toppled in 2012, and Wang Yang, a Politburo member serving at that time as Party Secretary of Guangdong, had debated the idea of the CPC having to earn its right to rule, rather than this being something that was simply handed to it as a divine right. ${ }^{13}$ The fact that a debate like this needed to happen in the first place was an acknowledgement, albeit covertly, that the CPC had a highly ambiguous role in China. In some ways, it operated like a state within a state, above and beyond the law, with something approaching uncontested sovereignty. And yet in other contexts, from ideology to its propaganda, it presented itself as the servant of the people. The Party was both privileged, the recipient of an incontestable mandate to rule, but also seeking ways, in a society where its ideological hold was growing more and more elusive, in which it could demonstrate validity to the wider world beyond its membership that was not just based on force, fear, and coercion but something approaching an idea of service and legitimization through performance.

\footnotetext{
${ }^{9}$ See Four Comprehensives Wins Public Acclaim. Global Times. February 27, 2015, at http://en.people. $\mathrm{cn} / \mathrm{n} / 2015 / 0227 / \mathrm{c} 90785-8854547 . \mathrm{html}$

${ }^{10}$ This is analyzed in [14]. CEO China: The Rise of Xi Jinping, Chapter Three. London and New York: I B Tauris.

${ }^{11}$ China's Xi Jinping Unveils new 'Four Comprehensives' Slogans. BBC. February 25, 2015, at http://www. bbc.co.uk/news/world-asia-china-31622571

${ }^{12}$ Xi Jinping zai dang de qun zhong luxian jiaoyu shijian huodong zong jieda huishang de jianghua. Xinhua. October 8, 2014, at http://news.xinhuanet.com/politics/2014-10/08/c 1112740663.htm

${ }^{13}$ On these debates, see [15]. The New Emperors: Power and the Princelings in China, 85. London and New York: I B Tauris.
} 
The 'Four Comprehensives' did in fact revert to earlier tropes of propaganda and ideological campaigning. As American expert on the Chinese language, Perry Link, has pointed out that the CPC, throughout its history, had given itself over to numerical slogans. The Three Antis had been one of the earliest mass campaigns in the 1950s, and this had been followed by a plethora of others. (See [5]) One of the issues during the Hu era, however, was the sort of emotional disengagement that this formulaic language created. Liu Yunshan, at that time head of propaganda in the Politburo, admitted in 2005 when talking to cadres at the Central Party School, one of the key training centres, that the language of the CPC had become ossified and remote, with speeches that succeeded in putting people off, even amongst the CPC membership. Such criticism of Party discourse was not new. Mao Zedong had in an earlier period railed against the language that Party bureaucrats used. 'In the past, some of our high-ranking cadres did not have a common language even on basic theoretical problems of MarxismLeninism,' he complained in 1949. This search for a common language has been an on-going mission of the CPC ever since. ( [16], Vol. 4, 377) Hu's style typified this, with no reference to personal history, likes or passions, and the dense use of terms from conventional Chinese Marxist ideology. At a time when Chinese society was undergoing an almost daily transformation, with the pace of life accelerating economically, culturally and socially, a disconnection emerged - the discourse of central leaders seemed to be the one remaining oasis of unchanged calm in the midst of all this dynamism.

Xi Jinping has been willing to deploy a more direct register in his language. The 'China Dream' (Zhongguo meng), a term widely used in the public sphere since 2013, is the most striking in terms of emotional resonance, despite the vagueness in official discourse about what it actually means. The concept was first mentioned by $\mathrm{Xi}$ in November 2012, defining it when speaking in the US two years later as 'a dream of the people. We can fulfil the Chinese dream only when we link it with our people's yearning for a better life. ${ }^{14}$ In some senses, this was a development of the "person as the core' theme from the $\mathrm{Hu}$ era, as discussed above. But there were multiple definitions of the 'dream' idea, with the slogan appearing on hoardings across China. The phrase itself spoke to public aspirations and imaginations about what life in a wealthier, more prosperous country could be like. $\mathrm{Xi}$ was evidently willing to appeal to these aspirations, coming up with a CPC 'secular' ideology - a way of thinking that went beyond the confines of traditional Party ideological boundaries and reached out into the wider social world. This emotional element was something that typified a number of the other key aspects of ideology and its language under $\mathrm{Xi}$, as the following discussion on keywords appearing in this era will reveal.

\section{Xi's Keywords}

Chinese leaders like to talk. They are fond of making speeches, which are then covered in detail in official newspapers, on state-run television, and which often become core planks of the Party's propaganda campaigns. Within this leadership discourse, there are

\footnotetext{
${ }^{14} \mathrm{Xi}$, Jinping. Full Text from Speech in Seattle. National Committee on U.S. China Relations. September 2015, at https://www.ncuscr.org/content/full-text-president-xi-jinpings-speech
} 
certain commonalities and patterns. Keywords, as the work of Qian Gang, Bandurski and others have shown, rise and fall in terms of their currency. What are the core series of words for $\mathrm{Xi}$, and what clues do they give as to the underlying ideological preoccupations of the Party in the China he leads?

First of all, we need to think about the genealogy of the term 'Keywords' itself. It was a Cambridge scholar, Raymond Williams, who popularized the concept in his celebrated 1976 book, 'Keywords: A Vocabulary of Culture and Society'. He analysed around one hundred words which had proved influential and important in the discourse of leftist political development in the UK, moving beyond their etymologies to what he called their change over time according to the different social, cultural and political contexts in which they were situated. 'I called,' he wrote, 'these words Keywords in two connected senses: they are significant binding words in certain activities, and their interpretation; they are significant, indicative words in certain forms of thought.' ([17], 1983, 15) A focus on keywords has proved fruitful in scholarship about Chinese political discourse. ${ }^{15}$ For $\mathrm{Xi}$, there are 12 distinctive terms that have been promoted as part of a campaign since 2014-15 to support socialist values. These are the keywords of the Xi era.

Fuqiang - 'strong', a term with deep resonance in modern Chinese rhetoric and practice. This first appeared in the late Qing, at the end of the nineteenth century, when it was deployed by modernizers such as Kang Youwei and Liang Qichao to indicate their desire for a modernized, stronger China which emulated the Meiji era of Japanese reforms of the mid-1860s. The concept of a 'strong' but also rich China appeared throughout the Republican Period, referencing back to the era of colonial humiliation, when a backward China was attempting to face down the modernized military and economic forces of both the West and Japan. After 1949, the term was to remain within Chinese political discourse despite the radical political changes, with Mao, Deng and almost every other leader using it to point out the aspiration of building a country that would never again be the victim of foreign aggression.

Minzhu - 'democratic' - used here in the very specific context of 'democracy with Chinese characteristics', literally the 'power of the people', as represented by the CPC. Mao Zedong had written extensively about the term 'new democracy' in January 1940, stating that 'the Chinese democratic republic which we desire to establish must now be a democratic republic under the joint dictatorship of all anti-imperialist and anti-feudal people led by the proletariat, that is, a new-democratic republic, a republic of the genuinely revolutionary new Three People's Principles with their Three Great Policies. ${ }^{\text {, }}$ The use of 'democracy' in recent years in Chinese political discourse has pushed back against the perceived annexation of this term by western liberal democracies. This use, therefore, asserts an indigenized iteration, one which, as Document Number Nine issued by the Chinese propaganda organs in 2013 made clear, was uncontaminated by ideas of western bicameral parliamentary systems, multi-party democracy, and the separation of powers. 'Democracy' here means democracy for the Party, by the Party, on behalf of the Party, all of which act as servants of the people they serve.

\footnotetext{
${ }^{15}$ See for good examples: [18]. Watchwords. http://cmp.hku.hk/watchwords2012/ or [19]. China in Ten Words. New York: Anchor Books or [20]. Words and their Stories. Leiden: Brill.

${ }^{16}$ Mao, Zedong. On New Democracy. In Selected Works, at https://www.marxists. org/reference/archive/mao/selected-works/volume-2/mswv2_26.htm
} 
Wenming - 'cultured/civilized' as opposed to 'wenhua', culture/al, which is a term still overshadowed in political language by the 'Cultural Revolution'. Linked to notions such as 'improving the quality of the population' (tigao renmin de suzhi) that had appeared in the mid 1990s, this asserts a notion of Chinese social civility, based on its 'five thousand years of continuous civilization' and pushes back against the notion of a country that is backward and undeveloped.

Hexie - 'harmonious' - discussed above in the context of Hu Jintao, who had made intensive use of this term in the 2000s, and linked to classical concepts introduced by ancient philosophers from Confucius to Mencius. This term had been lambasted by bloggers because of the ways in which its Chinese language version was also a homonym for 'river crab'. Despite this, and in an era of deepening social tensions and conflict, this term remains as important, albeit contextualized in a wider marketplace of terms, as before. It is seen as part of a process of moral urging on the part of the CPC in response to a society fragmented by material wealth and other differences, drawing attention to the catastrophic results of disunity in the past, and calling for continued focus on the collective goals of achieving a 'rich, strong, powerful' country, as mentioned above. 'Harmony' plays to ancient notions of order and hierarchy, ranging from the 'Tianxia' (all under heaven) notion to the sense adopted from $\mathrm{Hu}$ onwards of maintaining social stability and preventing conflict in society. This gives 'harmonious' a slightly ambiguous role in contemporary Chinese discourse - an invitation to unity and joint purpose, but also a slight threat to those who raise any objections to the means used to achieve this. Thus, the deep irony is that the term 'to be harmonized' is applied to those who are to be silenced or simply locked up when their ideas become too contrarian.

Ziyou - 'freedom'. This again is a term that sits awkwardly within Chinese political discourse in the PRC, being linked to notions from outside China of free elections and western liberalism. As with 'democracy', this figures as an attempt to situate a word in a CPC context in which it is decontaminated and pacified. The term is particularly loaded as it appeared in the slogans used by demonstrators during the June 1989 unrest. In $\mathrm{Xi}$ era discourse, it largely applies to the notions of economic empowerment, and the freedoms of the Chinese to own their own homes, travel where they wish, and have a new status in the outside world, in response to the way in which the country has not been respected and admired in the past. In this sense, Chinese people have never been more free, although, under $\mathrm{Xi}$, the boundaries of this freedom have been more tightly drawn.

Pingdeng - 'equality'. This a recognition of the huge disparities that exist in Chinese society as a side effect of the reform process and transformations in the economic realm. 'Pingdeng' figures as an acknowledgment that the Party needs to serve its socialist mission of delivering balanced growth for all, which collides with the recognition within and outside China that there are huge inequalities. This term, in particular, marries up with the more traditional ideological commitment of the CPC to create a society along Marxist-Leninist lines, where people strive for a society characterized by common ownership and the collective achievement of development goals.

Gongzheng - 'justice'. This is linked to the term below, i.e., legality, and asserts the Party's acknowledgement that it has to govern for and on behalf of all, and that since 1978 the rights consciousness of Chinese people has risen sharply. The desire for justice lies at the heart of the many millions of petitions addressed to the central 
government, and the recourse to courts in the civil realm. But justice is a term the Party also circumscribes. It controls the sources, as well as the definitions, of justice.

Fazhi - 'rule of law', is a term linked to the clear criticisms levelled during the era of Maoism, when there was 'rule of man, rather than of law.' This challenges the notion of Chinese society being one that asserts the primacy of relationships and influential connections (renqing, guangxi) and other networks over the implementation of objective laws. Linked to notions of justice and equality, the Chinese Plenum in 2014 concentrated on the notion of 'rule of law', whereby there were stronger, more predictable regulations for property, commercial issues, etc., but where the Party itself remained immune from attack by activist, and in the Party elite's eyes politicized, lawyers.

Aiguo - 'patriotism', indicates an acknowledgement that under $\mathrm{Xi}$, as under $\mathrm{Hu}$ and Jiang, one of the most important new sources of legitimacy for the CPC is to appeal to its patriotic, national mission. The 'patriotic' education campaigns of the mid 1990s stressed the ways in which a strong country (see term one above) was also linked to a stable, strong party, and that this was the surest way of delivering a country which would never again be subject to the nightmares of humiliation that it had suffered since the middle of the nineteenth century. The more negative outcome of 'aiguo' has been the rise of more assertive nationalism and its impact on China's relations with the outside world. $^{17}$

Jingye - 'dedication', is a less frequently used term, which relates to notions of the Party seeking not just people's loyalty in exchange for material gain, but also their deeper commitment to a mission they identify and share with the CPC - the creation of a stable, sustainable, rich, strong Chinese state. This is linked to the notion of 'trust', covered below.

Chengxin - 'trust', is another term, like the one above, that has figured little in Chinese political discourse, largely through the chronic lack of trust that the Chinese people have tended to have in their political leaders, exemplified in trust surveys which have shown that while doctors, teachers, and even sex workers enjoy greater levels of trust within China, national leaders, and in particular local leaders, have an immense challenge to overcome. ([22], 142-143) This lies at the heart of Xi's words in November 2012, when he outlined the need to repair the damage done by corrupt officials within the Party, and to close the gap between the rulers and the ruled. This concept also correlates with Xi's concept of the 'Four confidences' (sige zixin), formulated throughout 2016 - i.e., confidence in the path, theory, system, and culture of a socialism with Chinese characteristics. ${ }^{18}$

Youshan - 'friendly'. This expression promotes the notion that China, as well as the Chinese people and the Chinese Communist Party and government, are not a threat, but wish to establish friendly relations with the wider world, promoting 'win win outcomes.' This lies at the heart of the soft power campaigns that the central government has supported since the $2000 \mathrm{~s}$, a 'China that is a friend to all the world.'

\footnotetext{
${ }^{17}$ Elizabeth Perry shows that cultural nationalism has been a key part of the CPC's mission since the 1920s, and very strongly so under Mao. [21]. Cultural Governance in Contemporary China: "Re-Orienting" Party Propaganda. Harvard University. At http://www.harvard-yenching.org/features/hyi-working-paper-serieselizabeth-perry

${ }^{18}$ See Feng Pengzhi. Cong sange zixin dao sige zixin — lun Xi Jinping zongshuji dui Zhongguo tese shehui zhuyi de wenhua jiangou. July 7, 2016, at http:/theory.people.com.cn/n1/2016/0707/c49150-28532466.html
} 
These terms exhibit a number of attributes. They indicate a willingness to mix terms more closely associated with China's classical philosophical heritage (hexie for instance) and to indigenize other terms that have been taken from external discourses (minzhu). This, as well as terms such as gongzheng, are taken from their more common external roots and placed within a Chinese cultural context, but one which transforms their political implications through linking them to an overarching narrative that sponsors and supports the CPC. These keywords also map out a terrain that is neither overtly intellectual, formulaic, nor emotional, but which attempts to address each of the core areas. In this sense, they do provide a comprehensive core vocabulary. The only issue is that 12 such different terms are hard to meld together into a coherent whole. They often appear in placards in Beijing and other places as a list, just as they are presented here, with no overarching sense of the master narrative to which they belong. In what ways, therefore, do they contribute to a master Party narrative in the China of $\mathrm{Xi}$ himself and what actions do they sponsor?

\section{Xi's Ideology in Action - The Transformation of China into a "Spiritual Civilisation"}

What sort of world is the CPC trying to create through the delivery of these 12 keywords? The term 'spiritual civilisation' and the notion it covers, i.e., 'Socialist spiritual civilisation ${ }^{19}$ construction', first appeared during the post-Mao discursive shift and has since been used by Deng Xiaoping, among others. This phrase spells out more clearly than any other the grand aim of the Party, its power and the contemporary discourse of ideology that drives it.

The role of 'socialist spiritual civilization' has never been as strong as it is today. In the 1986, "Central Committee of the Communist Party of China Resolution on the Guidelines of the Construction of Socialist Spiritual Civilization", ${ }^{20}$ the term itself only appears as the fourth term within the socialism modernization strategy. The first to be posited in this document, economic development, stands at its core, followed by reform of the economic system, political system reform and, finally, spiritual civilization construction. The main task is explained as to 'adapt to the needs of socialist modernization construction, to foster socialist citizens with ideals, morals, culture, and discipline, and to improve the moral qualities of the thought and scientific culture qualities of the Chinese nation as a whole'. Informing people about socialist culture can be seen as the key role of this concept. Constructing a spiritual civilization, as presented by Deng Xiaoping, is an addition to the construction of material civilization, (wuzhi wenming jianshe), thus forming 'the two civilizations (liang ge wenming). Just as during the Cultural Revolution of 1966 and onwards, the aim was to 'remake man' but not in the often brutal manner adopted in that turbulent decade. Instead, the aim was a synthesis, a harmonious balance between the two.

\footnotetext{
${ }^{19}$ The Japanese-coined element wenming contains multiple readings. It can take both a noun position civilization, culture, to refer to a certain distinct ethnic/historic/political group, and an adjective position civilized, in a sense, enlightened, to refer to a social value, something that every individual and the community as a whole should strive for.

${ }^{20}$ Zhonggong zhongyang guanyu shehui zhuyi jingshen wenming jianshe zhidao fangzhende jueyi. At http://cpc.people.com.cn/GB/64162/64168/64565/65381/4429515.html
} 
It was in order to promote this idea of public morality, in line with CPC ideology, and to service the needs not just in terms of the material but of the whole person, that campaigns to promote 'civility' and 'being civilized' were launched throughout the 2000s. Never quite disappearing from the public sphere, the element also made an appearance in Hu's speeches, presented as something that was not to be sacrificed during a time of rapid economic growth. ${ }^{21}$ However, from 2012 onwards, the 'spiritual civilisation' concept entered a new phase. Starting from the 18th Congress, the main line of the spiritual civilization construction agenda was to cultivate and practice core Socialist values, to promote truth, goodness, and beauty, as well as to spread positive energy throughout the whole of society and to generate a strong spiritual power within hundreds of millions of people. It is evident that on comparing the 1986 document, the concept is still in place, although its constituent elements have been remodelled. They are now part of a much grander aim - to make one party rule sustainable and to push China towards the goal of being a great and strong nation by the achievement of the first centennial goal by 2021 .

When addressing the topic of 'spiritual civilisation' in his speeches, Xi stresses continuity and quotes Deng Xiaoping. ${ }^{22}$ Despite this, innovations in the concept are evident. In Xi's interpretation, the phrase has undergone both a promotion and a facelift.

First of all, Xi stresses the utmost importance of 'spiritual civilisation construction', and puts it at the centre of core Socialist values: 'The construction of spiritual civilization needs to be inserted into the full process of the reform and opening up, and the modernization, introduced into all aspects of social life, and tightly combined with the cultivation and practice of Socialist core values. ${ }^{23} \mathrm{Xi}$ stresses the craving for the "China story' to be heard all around the world, and this can be achieved via an exposition of the 'excellent Chinese culture'- yet another intrinsic component of the core values. (ibid.)

Secondly, Xi Jinping demonstrates ownership of the concept, using it alongside his signature keywords: 'China dream' and 'the four comprehensives'. ${ }^{24}$ The new link has not gone unnoticed among Party School think tankers such as Professor Zhang Rongchen, who has called for a 'focusing on the 'four comprehensives', promoting the development of civilization. ${ }^{, 25}$ Furthermore, Xi has stressed 'spiritual civilisation', a key factor within the building of the moderately prosperous society (xiaokang shehui) objective, thus showing 'spiritual civilisation' to be a part of the first Centennial goal.

Thirdly, Xi Jinping centres his new personal 'people have faith, nation has hope, country has power' (renmin you xinyang minzu you xiwang guojia you liliang ${ }^{26}$ punch

\footnotetext{
${ }^{21} \mathrm{Hu}$ Jintao: Buneng yi xisheng jingshen wenming wei dai jiahuan qu jingji fazhan. February 18, 2008, at http://www.chinanews.com/gn/news/2008/12-18/1492724.shtml

22 See Xi Jinping zai jinian Deng Xiaoping tongzhi danchen 110 zhou nian zuotanhui shang de jianghua August 20, 2014, at http://news.xinhuanet.com/politics/2014-08/20/c 1112160001.htm

23 " Shiyi. Yong shehuizhuyi hexin jiazhiguan ningxin juli guanyu jianshe shehuizhuyi wenhua qiangguo Xi Jinping zongshuji xilie zhongyao jianghua duben. (2016), May 5, 2016, at http://politics.people.com.cn/n1 /2016/0505/c1001-28325813.html

${ }^{24} \mathrm{Xi}$ Jinping zongshuji zai huijian quanguo jingshen wenming jianshe gongzuo xianjin daibiao shi de zhongyao jianghua jingshen. March 3, 2015, at http://www.gov.cn/xinwen/2015-03/03/content_2825041.htm ${ }^{25}$ Shehuizhuyi jingshen wenming jianshe wei chuangzao wuzhi wenming fazhan de shijie qiji tigong le fengshuo de jingshen wenming chengguo. April 1, 2015, at http://theory.people.com.cn/n/2015/0401/c8384826784810.html

${ }^{26} \mathrm{Xi}$ Jinping: renmin you xinyang minzu you xiwang guojia you liliang. February 28, 2015, at http://news. xinhuanet.com/politics/2015-02/28/c_1114474084.htm
} 
line around the 'spiritual civilisation' notion. Deemed to be of great importance by the PRC media and containing a straightforward 'strong China' narrative, the slogan illustrates that a country can only be great if people have faith and hope in its future. That can be achieved by constructing a spiritual civilization, spreading 'excellent Chinese traditional culture' (Zhongguo youxiu chuantong wenhua) and core Socialist values. Xi Jinping demonstrates his eagerness to adopt traditional culture right there and then, recruiting the Confucian family-country parallel.

To conclude, it can be argued that the main focus of the discourse element 'spiritual civilisation' has shifted from Deng Xiaoping's introduction of the reform and the opening up of Socialist culture and the balancing of economic goals, to the applied civility-promotion campaigns of Hu's time, all the way to the stressing of the uniqueness of the Chinese civilization and the notion of proud nation frameworkbuilding during the $\mathrm{Xi}$ era. In the light of $\mathrm{Xi}$ ' $\mathrm{s}$ dismissal of Western values as not being suitable for China, the concept of 'spiritual civilisation' represents an attempt to contribute to a home-grown value alternative - a non-consistent traditional ingredient mixed in with Socialist ethos-in-transition, known as the Socialist core value outlook (shehui hexin jiazhiguan). ${ }^{27}$

\section{Conclusion: Xi's Ideological Features}

What are the dominant features of CPC ideology under Xi Jinping? What can we read into the ordering of official discourse around a number of core keywords? These now link the Party with its ideological positions of the past, stressing its socialist heritage, but also with the larger hinterland of Chinese philosophical thinking that stretches back deep into the imperial era. They occupy a more comprehensive space, one that also attempts to relegitimise the CPC by making an emotional, rather than just intellectual, appeal. They tap into nationalism, the aim of national rejuvenation through attaining great nation status, and appeal to the current profound sense amongst Chinese people of their being justified in wanting to move from a history of victimhood to one of agency, pride, global recognition and power. Current ideology can work in this society because it serves the longing of China to appear strong and united - a country with a Plan - in the eyes of the international community. A claim can be made that inconsistencies, such as declaring the "Rule of law" and then immediately cracking down on human rights advocates, can be forgiven because undermining the ideology can lead to the destabilization of China's claim to be offering 'two guides' on a global scale, i.e., guiding the world towards a new international order and towards a safeguarding of international security. ${ }^{28}$

On an internal scale, the message of continuity contained in CPC ideology helps society to avoid the embarrassment of having to break the ties with its past, hence foregoing the toxic disruption of social solidarity experienced in post-Soviet Russia.

\footnotetext{
${ }^{27}$ For Xi Jinping's discursive unification of the traditional and the Socialist within the Socialist core values concept, see: Xi Jinping zai Zhonggong zhongyang zhengzhiju dishisan ci jiti xuexi shi qiangdiao ba peiyu he hongyang shehuizhuyi hexin jiazhiguan zuo wei ninghun juqi qiang ji gu ben de jichu gongcheng. February 26, 2014, at http://paper.people.com.cn/rmrb/html/2014-02/26/nw.D110000renmrb_20140226_2-01.htm

${ }^{28} \mathrm{Xi}$ Jinping shouts "linage yindao" you shenyi. February 21, 2017 at http://www.ccln.gov. $\mathrm{cn} /$ hotnews/230779.shtml
} 
Manoeuvres and changes in policy are, therefore, less traumatizing, being attributed to the "correction of mistakes" and to "learning from experience".

In the 1980s and the two decades thereafter, the Party went through a series of crises in relation to its function and the need to maintain faith with ideology in order to stay in power. These ranged from the Tiananmen Square massacre of 1989 to the collapse of the Soviet Union in 1991, followed from the late 1990s onward by the breakneck enrichment programme and the temptations this offered to Party officials and society. In the era of $\mathrm{Hu}$, China increasingly seemed to be a capitalist society in all but name, with the CPC behaving like a massive business operation, one which paid only lip service to the ideology it was meant to be serving.

Under $\mathrm{Xi}$, we have seen a return to more focused political commitments, based on an acknowledgement that the great prize of national rejuvenation is within sight and an awareness that the Party must maintain organizational unity and discipline in order to achieve this. This future is already being mapped out with the talk of centennial goals. In this new context, ideology supplies a precious elite unity, a common language of power, while also promoting a particular vision of society. Through the 12 keywords mapped out above, the objectives of the Party in the twenty-first century are revealed, appealing not just to the material needs of people, but to their wider aspirations. This lies at the heart of the 'spiritual civilization' language. Ideology in Xi's China is important because of the ways it enforces unity, creates a common purpose, and operates as a means of guiding the country, under the direction of unified CPC rule, towards its great objective - modernization with Chinese characteristics.

Open Access This article is distributed under the terms of the Creative Commons Attribution 4.0 International License (http://creativecommons.org/licenses/by/4.0/), which permits unrestricted use, distribution, and reproduction in any medium, provided you give appropriate credit to the original author(s) and the source, provide a link to the Creative Commons license, and indicate if changes were made.

\section{References}

1. Eagleton, T. 2007. Ideology: An Introduction, 2-3. London: Verso.

2. Schurmann, F. 1965. Ideology and Organisation in Communist China. Berkeley: University of California Press; and Hsiung, J.C. 1970. Ideology and Practice: the Evolution of Chinese Communism. London: Pall mall press, London, esp. chapters 6 and 7, 106-147.

3. Hsiung, J.C. 1970. Ideology and practice: The evolution of Chinese communism. London: Pall Mall Press, London.

4. Brown, K., and S. von Neuwenhuizen. 2016. China and the New Maoists, 1-32. London: Zed Books.

5. Link, P. 2013. An anatomy of Chinese: Rhythm, metaphor and politics. Cambridge: Harvard University Press.

6. Schoenhals, M. 1992. Doing things with words in Chinese politics. Berkeley: University of Berkeley Press.

7. Pantsov, A.V., and S.I. Levine. 2015. Deng Xiaoping: A revolutionary life. Oxford: Oxford University Press.

8. Deng, Xiaoping. 1992. Excerpts From Talks Given in Wucheng, Shenzhen, Zhuhai, and Shanghai. Beijing: Foreign Languages Press.

9. Wu, G.G. 2015. Paradoxes of China's Prosperity: Political Dilemmas and Global Implications, 244. London: World Scientific.

10. Dikötter, F. 2008. The age of openness: China before Mao. Berkeley: University of California Press.

11. Jintao, H. 2007. Documents of the 17th national congress of the communist party of China. Beijing: Foreign Languages Press. 
12. Wedeman, A. 2012. Double paradox: Rapid growth and rising corruption in China. Ithaca: Cornell University Press.

13. Xi, Jinping. 2015. Xi Jinping tan zhiguo lizheng. Beijing: Waiwen Chubanshe.

14. Brown, K. 2016. CEO China: The Rise of Xi Jinping, chapter three. London: I B Tauris.

15. Brown, K. 2014. The New Emperors: Power and the Princelings in China, 85. London: I B Tauris.

16. Mao, Tse-Tung. 1961. Methods of work of party committees. In Selected works of Mao Tse-Tung, volume 4, 377. Peking: Foreign Languages Press.

17. Williams, R. 1976. 1983. Keywords: A Vocabulary of Culture and Society, 15. Revised edition, Crome Helm. London: Fontana.

18. Qian, G., Bandurski, D. 2012. Watchwords - Reading China Through its Party Vocabulary. http://chinamediaproject.org/about/. Accessed 20 Sept 2017.

19. Yu, H. 2012. China in ten words. New York: Anchor Books.

20. Wang, B. 2011. Words and their stories. Leiden: Brill.

21. Perry, E.J. 2013. Cultural governance in contemporary China: "Re-Orienting" party propaganda. Harvard University. http://www.harvard-yenching.org/features/hyi-working-paper-series-elizabeth-perry. Accessed 25 Sept 2017.

22. Dickson, B.J. 2016. The Dictator's Dilemma: The Chinese Communist Party's Strategy for Survival, 142-143. Oxford: Oxford University Press.

Kerry Brown is Professor of Chinese Studies and Director of the Lau China Institute at King's College, London. Prior to this, he was the Professor of Chinese Politics and Director of the China Studies Centre at the University of Sydney. He led the Europe China Research and Advice Network (ECRAN) funded by the EU from 2011 to 2014. He is an Associate Fellow on the Asia Programme at Chatham House, London. His main interests are in the politics and society of modern China, in its international relations and its political economy. Educated at Cambridge (MA), London (Post Graduate Diploma in Chinese with Distinction) and Leeds Universities $(\mathrm{PhD})$, he worked in Japan and the Inner Mongolian region of China, before joining the Foreign and Commonwealth Office (FCO) in London in 1998. He worked in the China Section and then served as First Secretary, Beijing, from 2000 to 2003, and Head of the Indonesia East Timor Section at the FCO from 2003 to 2005

Una Aleksandra Bērziṇa-Čerenkova is Head of Riga Stradins University China Studies Centre and Head of the New Silk Road programme at the Latvian Institute of International Affairs. She has a PhD in Political Science. The topic of her thesis was “Traditional Chinese Discourse in Hu Jintao's Report to the 17th National Congress of the Communist Party of China". She has a Bachelor's degree in Chinese language and culture (with Distinction), and a Master's degree in Political Science. Her research focus lies in the field of contemporary political discourse in the PRC. She has studied at both Beijing Language University and Beijing Normal University. She spent two semesters as a senior visiting research scholar at Fudan University School of Philosophy, Shanghai. 